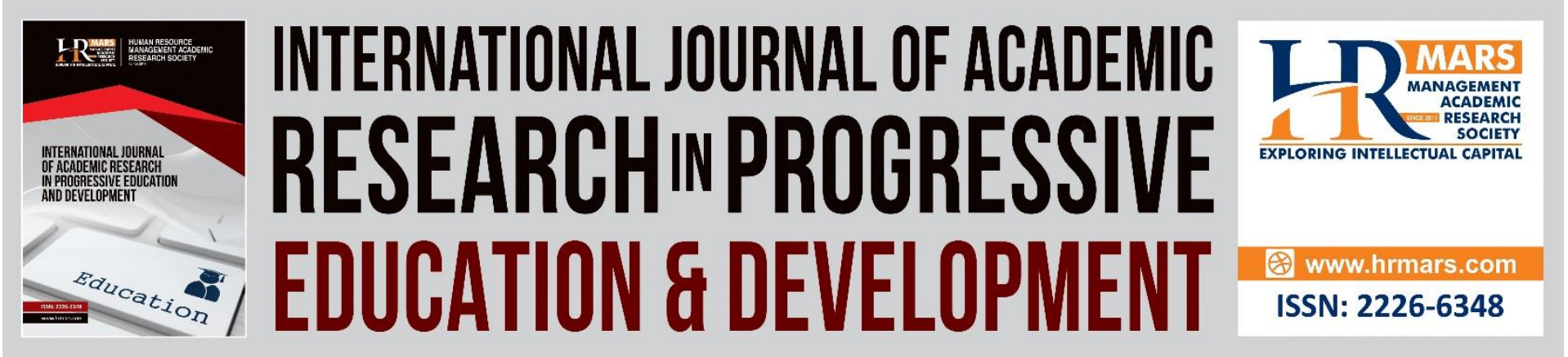

\title{
The Use of Mobile Apps as Strategies in Teaching Vocabularies among English Teachers
}

Muhamad Fizri Jamal, Harwati Hashim, Izzati Esa

To Link this Article: http://dx.doi.org/10.6007/IJARPED/v10-i3/10833

DOI:10.6007/IJARPED/v10-i3/10833

Received: 09 June 2021, Revised: 12 July 2021, Accepted: 28 July 2021

Published Online: 28 August 2021

In-Text Citation: (Jamal et al., 2021)

To Cite this Article: Jamal, M. F., Hashim, H., \& Esa, I. (2021). The Use of Mobile Apps as Strategies in Teaching Vocabularies among English Teachers. International Journal of Academic Research in Progressive Education and Development, 10(3), 265-274.

Copyright: (C) 2021 The Author(s)

Published by Human Resource Management Academic Research Society (www.hrmars.com)

This article is published under the Creative Commons Attribution (CC BY 4.0) license. Anyone may reproduce, distribute, translate and create derivative works of this article (for both commercial and non-commercial purposes), subject to full attribution to the original publication and authors. The full terms of this license may be seen

at: http://creativecommons.org/licences/by/4.0/legalcode

Vol. 10(3) 2021, Pg. 265 - 274

http://hrmars.com/index.php/pages/detail/IJARPED

JOURNAL HOMEPAGE

Full Terms \& Conditions of access and use can be found at http://hrmars.com/index.php/pages/detail/publication-ethics 


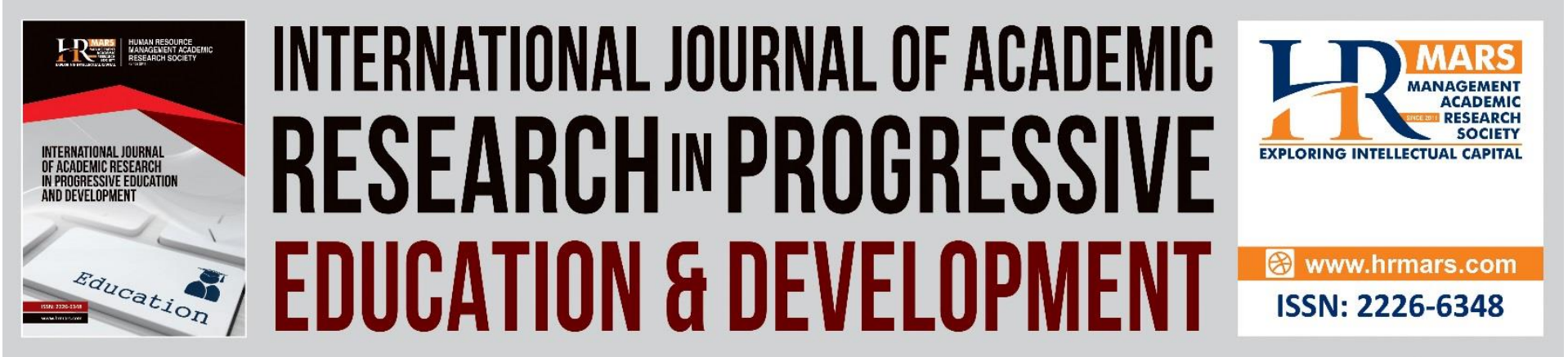

\title{
The Use of Mobile Apps as Strategies in Teaching Vocabularies among English Teachers
}

\author{
Muhamad Fizri Jamal ${ }^{1,2}$ \\ ${ }^{1}$ Faculty of Education, Universiti Kebangsaan Malaysia, Malaysia, ${ }^{2}$ Sekolah Kebangsaan Parit \\ Lapis, Batu Pahat, Malaysia \\ Email: fizrijamal@gmail.com \\ Harwati Hashim \\ Faculty of Education, Universiti Kebangsaan Malaysia, Malaysia \\ Email: harwati@ukm.edu.my \\ Izzati Esa ${ }^{1,2}$ \\ ${ }^{1}$ Faculty of Education, Universiti Kebangsaan Malaysia, Malaysia, ${ }^{2}$ Sekolah Kebangsaan Seri \\ Binjai, Batu Pahat, Malaysia \\ Email: izzatiesa@gmail.com
}

\begin{abstract}
Studies had proved that acquiring wide range of English vocabularies is essential to be proficient English users. For ESL learners, there are various learning strategies that can be used to learn vocabularies and ESL teachers play significant part in this matter. One of the efficient ways is to integrate technology in the learning process. Even though computers are being used widely in the educational field, the role of mobile phones and mobile applications are becoming more prominent these days. This paper reflects the use of mobile applications (mobile apps) as strategies in teaching vocabularies among English teachers. Many studies show that the use of mobile applications in teaching can attract students' interest and increase their engagement in the learning. As a result, students can acquire more vocabularies compared to the traditional teaching method. Nevertheless, teachers and educators must be equipped with ample knowledge to conduct the learning using mobile apps efficiently and must take account students' social and economic background. Future research is recommended to empirically prove this finding as well as to identify potential gaps that might exist.
\end{abstract}

Keywords: ESL, Mobile Apps, Mobile Phones, Vocabularies, Technology Acceptance Model (TAM)

\section{Introduction}

Communication is one part of humans' life because in order to survive, we must live in communities. People communicate for many purposes such as for leisure activities and work 
based purposes. There are two types of communication; verbal and non-verbal. Language is comprised of vocabularies and it is the key for verbal communication. Language has given human being the ability to communicate with each other, forming a complex system of communication, and within each language vocabulary stands as the basis for the language (Ismail et al., 2017). Therefore, for us to be good language users and to communicate effectively, we have to acquire abundant vocabularies.

Moving up to the new era, people have varieties medium of communication and it all thanks to the progress in technology. There was a time where using facsimile machine and house phone / landline telephone were considered as advance means of communicating with each other. On the other hand, nowadays mobile phones have positioned themselves as one of the greatest things that had been invented. It is because, mobile phones are not just 'a phone' but it is like a mini computer with the connection to the internet. In this $21^{\text {st }}$ century, we can see a massive development in technologies and ICTs contributing toward the changing in many sectors and education field is not excluded.

Mobile phones have proliferated our daily lives to an extent that many confess to not being able to live without them (Makoe \& Shandu, 2018). Mobile applications (mobile apps) are easily downloaded from the apps market and are being used broadly by many groups of society including teachers and pupils. The creation of mobile applications (mobile apps) have added extra values to mobile phones. Recently, smart phones are less expensive, lighter and more powerful and they have been trying to find its way into language learning (Lei, 2018). Each day, we can witness that developers will come out with the latest mobile apps for social networking, business and educational field. Gangaiamaran \& Pasupathi (2017) agreed that countless apps can be downloaded easily through the internet.

In the process of growing up, people will pick up the first language (L1) in informal situations such as at their home or while communicating with the family members. Moving up to the $1^{\text {st }}$ grade or kindergarten level, the task of educating people with $1^{\text {st }}$ and $2^{\text {nd }}$ occasionally will be handed to the teachers. For English teachers, it is challenging for them to teach English to those who are non-native speakers. Thus, English teachers must use varieties approaches to teach vocabularies as it is a fundamental in mastering a language. Listening, speaking, reading and writing are four main skills for students have to master. Still, to practice those skills proficiently, students have to be equipped with vocabularies. Shen (2003) agreed that without vocabulary, it is difficult to communicate. As we concern, many scholars had proposed various teaching and learning strategies to suit the students and teachers' needs and situations. While teaching listening, speaking, reading and writing skills, ESL teachers usually will not neglect the importance of teaching vocabulary to the pupils as those skills are interrelated

The studies of vocabulary are categorized into two directions which are vocabulary learning strategies and learning assisted with technologies (Lei, 2018). Therefore, by following the current trend, teachers have started to take advantage of the modernization in mobile phones and mobile apps to assist the teaching and learning process. Vocabulary teaching is at the heart of developing proficiency and achieving competence in the target language (Basal et al., 2020). Conventionally, ESL teachers teach vocabulary using flashcards, textbooks, pictures and dictionary. Without sufficient vocabulary, people cannot communicate and write effectively. In fact, we need vocabularies not just for the purpose of mastering English language only but also to secure input from other fields. We need to know the language, so to speak, not simply in the sense of learning a first or second language but also in the sense 
of learning the vocabulary that characterizes some field of study, such as biology or the law (Bjork and Kroll, 2018). As one of the most important language in the world, people ought to be good in English for us to excel in any field of study. For the non-native speakers of English who face problems relating to the meanings of new words, spelling, pronunciation, correct use of words, guessing meaning through the context and so on, vocabulary learning can be tough (Afzal, 2019). For most Malaysian, English is not their L1 but as L2 and some are L3. Malaysians are like other non-native English users who are facing difficulties in learning English. Educators must prepare the students with language skills and adequate vocabularies. Hence, good teaching and learning strategies are demanded for the ESL learners to acquire a good range of vocabularies.

With the massive development of technology and mobile apps, there are teachers who opt out to use mobile apps as one of their teaching strategies. In addition, mobile apps offer wide range of selections to teachers as according to Wang (2017), for the past two decades, there are a lot of applications of educational activities on the Internet. There are many studies that had been done to review the benefits of using mobile phones in ESL from the students' perspective. For example, Basal et al., (2016): Effectiveness of Mobile Applications in Vocabulary Teaching, Deris \& Shukor (2019): Vocabulary Learning Through Mobile Apps: A Phenomenological Inquiry of Student Acceptance and Desired Apps Features and Kacetl \& Klímová (2019): Use of Smartphone Applications in English Language LearningA Challenge for Foreign Language Education. Conversely, there are limited researches that discuss how this approach is viewed from teachers' point of view and perspectives. Hence, this paper will review studies done on how mobile apps benefit and improve teachers' strategies in the teaching of vocabularies.

\section{Literature Review}

\section{Technology Acceptance Model (TAM)}

When we discussed on people's acceptance towards new technology and information system, there is one important theory that will definitely come across our trail which is Technology acceptance model (TAM). Basically, Tam was developed based on theory of reasoned action (TRA). However, according to Lee et al., (2003), the Technology Acceptance Model (TAM) is considered to be the most influential among all theories and it is commonly employed for describing and predicting an individual's acceptance of information systems. This theory was proposed by Davis in 1989 and mainly argued on two major factors that influence people's acceptance on technological innovation. These internal variables are; perceived usefulness (PU) and perceived ease of use (PEOU).

Davis defines perceived usefulness as the prospective user's subjective probability that using a specific application system will enhance his or her job or life performance (Surendran, 2012). PU depends on the user's belief whereby if the new technology can benefit him or her either in daily life or career or both. If it does, the user will definitely use the technology. For perceived ease of use (PEOU), it lingers on the user's belief that the use of the system can make his or her tasks become effortless and less difficult. Perceived ease of use is a belief that a user expects to not put much effort into making use of a particular system (Chang et al., 2012). External variables which are social factors, cultural factors and political factors also have great influences on PU and PEOU. Political state in a country might affect the use of technology in that country. If the state is in a crisis, for sure much fund will be channelled in order to maintain the peace and balance. According to Surendran (2012), social factors include language, skills and facilitating condition. To use the new technology 
efficiently, a user must possess adequate skills and language level as well as environment that can facilitate the user.

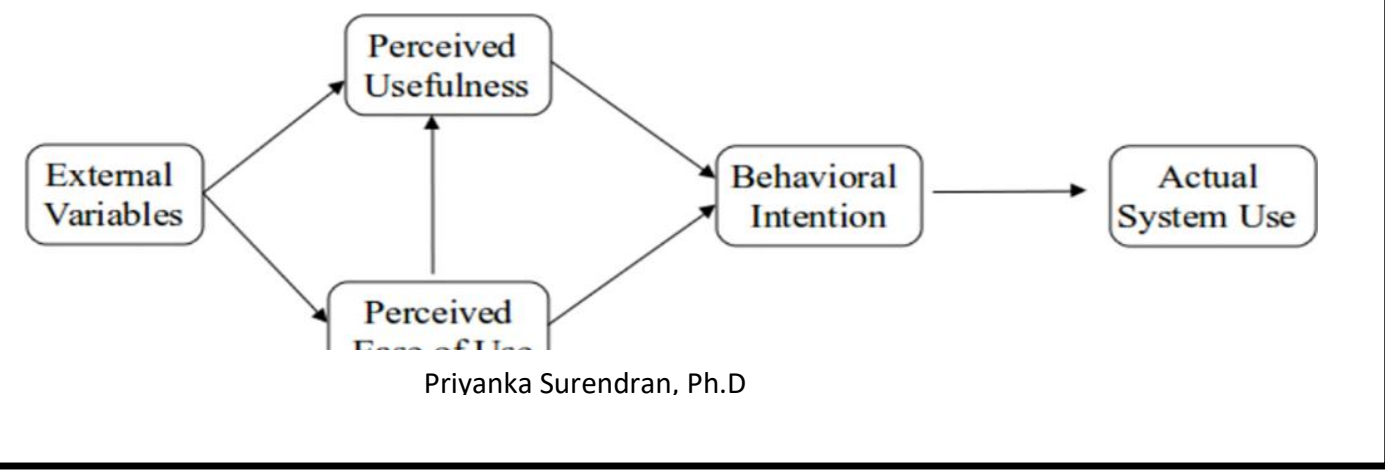

\section{Mobile Apps and Language Learning}

Hashim et al., (2016) claimed that mobile devices can be incorporated in learning to support the learners' ESL to improve their language competence. Due to the vast development in technology, mobile phones have becoming more affordable to us. It is common situations to see people especially the young generation to use mobile phones and mobile apps these days. Mobile phones and mobile apps are important because they help us to be multitasking in doing our chores. According to Kacetl \& Klímová (2019), " At present, hardly any younger person can imagine life without mobile technologies". They use them on a daily basis, including in language learning. Their research on the use of smartphone applications in English language learning showed m-learning offers great opportunity and a huge step forward in the learning field. However, they suggested that this method should be conducted with cares in order to create the authentic ESL learning environment.

Wang (2017) had conducted a pilot study in designing mobile apps for English vocabulary learning. It is due to the situation where English interface are used in most of the mobile apps for English learning purposes in Taiwan. It is not a problem with high achiever to use English interface but the problem is with the users who possess minimum English proficiency. Hence, the researcher had design the application with bilingual interface in English and Chinese language. Sample sentences, words and activities were specially designed for the apps. The results of the study showed positive feedbacks such as increased students' use of educational apps, cultivated students' self-learning habit and developed students' confidence in language learning.

Another study that is interesting to look into was done in 2019 by Pindeh and Mohd Suki. The study took a sight on user acceptance in using mobile apps as to learn Kadazandusun language. They believed that there was no study been conducted on this topic before. Hence, the conceptual paper which was guided by the Technology Acceptance Model aimed to contribute to the limited literature on the use of mobile technology for language learning particularly in learning Kadazandusun language (Pindeh et al., 2016). The variables are Content Richness, User Satisfaction, Perceived Usefulness and Perceived Ease of Use. The study claimed that Kadazandusun language contains high perceptions of rich and new sources content that can influence the users to use the mobile apps (perceive usefulness). In addition, their perceived ease in using mobile apps influences their attitude towards mobile app usage 
and purpose to use mobile apps. However, in the end the researcher proposed that future research must be done to test the proposed conceptual model and acquire empirical data.

\section{Vocabularies Acquisition in L2}

To become a proficient English language user, one must possess varieties of quality and one of the important aspects is wide range of vocabularies. Based on Teng (2014), vocabularies are consisted of 5,000 to 8,000 word families. It is challenging for learners with a limited vocabulary level to understand the texts and acquire words incidentally as native speakers. Many students realize the importance of vocabularies in learning English as a $2^{\text {nd }}$ language (L2) but it is tough for them to pick up the words because of many factors especially due to the complexity of English language which has different language system compared to their mother tongue.

Shen (2003) stated that when students learn a foreign language, many think that learning vocabulary is fundamental, important, but difficult. This shows that students and teachers are well aware to learn vocabularies but they must be exposed to the right and efficient teaching and learning strategies. This can be supported by the research done by Basal et al., (2020) which stated that vocabulary teaching is at the heart of developing proficiency and achieving competence in the target language. Consequently, scholars and academicians are putting more efforts in finding and developing the best approaches for teachers to teach and for students to acquire vocabularies.

\section{Behaviorism Theory}

In Behavioral theory, human behaviour is the result of learning, so it can be changed by manipulating and creating learning conditions (Budiman, 2017). This theory argued on imitation and repetition of people toward certain habit or condition that they have experienced before. As for the condition in the classroom, the teacher will strategize the lesson and use mobile apps as one of the tools in teaching vocabularies. Students will perform the task and activities in the classroom with teacher's guidance using the mobile apps. Through enough practice, students can imitate the same activities using their own mobile apps independently because the actions have become their habit. Vocabulary learning is not just acquiring new words but also the correct pronunciation as well as how they function in sentences. As a result, students can acquire more vocabularies by their own by imitating the activities done in the classroom. In the first place, in terms of the advantage, through the process of stimulus, response and reinforcement, the right behaviour can be strengthened and the incorrect behaviour will be corrected in time by the teacher (Xuelian, 2018). Students can always come back to their teachers for reference and guidance to reinforce the practice.

\section{Pedagogical Implication}

Language learning is evolving through times with the impact of advancement in technology, political stability and other factors. This will leave certain implications on pedagogical of ESL which this paper categorized it in three aspects; increase in students' engagement, promote creativity development and flexibility in teaching and learning. Krashen (1985) came out with his theory named The Affective Filter Hypothesis in which the affective filter, like a mental block, can control the access of comprehensible input to the Language Acquisition Device (LAD) for acquisition (Liu, 2015). He argued on the affective filter of learners and how it can affect the intake of new input. According to him, people acquire second languages only if they obtain comprehensible input and if their affective filters are low enough to allow the input 
'in'. Since mobile apps come in variations and with interesting features, this will make the process of teaching and learning more interesting and attract students' attention. This will lower down the students' affective filter and allow them to absorb more content of the learning. Mobile devices which are popular among students are motivational tools to be used in education as well as various learning activities (Hashim et al., 2017). The students will be more focus in their learning and the inputs are more meaningful. Hence, they will acquire more vocabularies while carrying out the tasks using mobile apps. One example of mobile apps that has interesting features named Talking Photos where we can edit any photos to make it talk. This can capture the students' interest and then lower down their affective filters. Abilene Christian University conducted another research and found that the kids were highly motivated to complete their lessons on mobile devices than the learning they have done through traditional textbooks and workbooks (Rao, 2018)

Other benefits of using mobile apps and its pedagogical impact is teaching and learning become more flexible and independent without neglecting the role of the teacher. Vocabulary acquisition depends not only on how learners learn, but also how they are taught (Ismail et al., 2017). Teachers are still needed for guidance purpose but students are given more room to participate in the learning process because students can use mobile apps outside of the classroom. For example, teacher can demonstrate on the steps to use the mobile apps in the classroom with relevant example. Later, students can practice the new input or repeat the same process outside of the classroom. Education is not only restricted to classroom learning (Rafiq et al., 2020). As in Malaysia context, most schools are still prohibited their students to bring mobile phones to classrooms due to certain reasons. Yet, this is not a barrier because the students can still utilize mobile apps outside of the school. The key features of m-learning, such as personalized learning, independent on time and place, collaboration with peers and teachers in both formal and informal settings, ubiquity and interactivity of mobile devices, make m-learning efficient (Kacetl \& Klímová, 2019). Online training can cater the needs of each individual and allow them to learn at their own pace (Rafiq et al., 2019). This will encourage self-learning among the students. By doing this, students are more exposed to the learning content and will boost their memorization of the new vocabularies.

Creativity is subjective where different people possess different level of creativity. People with good level of creativity can think out of the box and can produce something unusual. Some people need more stimuli to provoke their spirit of creativity. Even so, by using mobile apps, teachers and students' creativity can be enhanced because mobile apps come with different preface, functions, setting, sound / music and etc. Therefore, this will increase students' engagement in conducting or taking part in the lesson. The more they engage with the productive use of a word (say or write it, and create grammatical and collocational comparisons), the more likely that he/she is to master it (Schmitt, 2010). Students' maximum engagement in the lesson will help them to memorize and learn the new vocabularies better because the learning is more meaningful to them.

\section{Conclusion}

Teaching and learning are always evolving in times to keep up with the latest technology advancement as well as to fulfil the demands in educational fields. As the number of English learners is increasing, many different teaching methods have been implemented to assess the effectiveness of the teaching process (Pazilah et al., 2019). Besides, the new generations are much exposed to the current technology compared to the older generations. Young 
generations expect to be engaged in their learning and they do not do well being passive learners (Hashim, 2018). Therefore, the used of mobile apps can create active learning because the contents are more interesting and students are more motivated to learn. In addition, students are given more rooms and sources to be explored. Above all, teachers and educators must be equipped with ample knowledge to conduct the learning using mobile apps efficiently. Plus, teachers must consider the students' social, economic and family background because some students might have limitations to own and utilize mobile phones at home. It is suggested to conduct future research to have empirical findings and to identify potential gaps that might exist in implementing this learning strategy.

\section{Research Contribution}

Studies on the use of mobile apps in language learning can shift the dimensions in language acquisition from various perspectives. Initially, this research can create awareness among ESL teachers that there are unlimited sources to help them in constructing effective teaching strategies. Rao, P.S. (2019) claimed that teachers use mobile phones to get the information instantly in the classroom and also to visualize the learners some videos related to the topic. Teachers can download varieties of mobile apps to enhance their content richness and go beyond the scope while teaching the pupils. Information can be accessed faster and easier than before. On the other hand, pupils can be more independent learners with the help of mobile apps and technology. Majority of young generations are well exposed and smart with technology compared to previous one. Hashim, H. (2018) agreed that this generation is techsavvy and prefers to communicate using social media over direct contact with people. In addition, the use of mobile apps in learning can help students to cope with their busy life especially for tertiary and university level. For university students, the availability, convenience and low cost of mobile applications (apps) present new opportunities to fit learning into their busy lives outside class (Steel, 2012). According to Jones R. G. (2011), app development is currently progressing at a feverish pace, and app developers are in high demand. Thus, this paper also can give some insights to mobile applications developers in building mobile apps that are more user friendly, interactive but at the same time will not neglect the importance of social skill development. Learning English is mainly an attempt to communicate with individuals (Yang \& Chen, 2007). Hence, language based mobile apps should assist the learners in practicing English language and be better in communication.

\section{References}

Afzal, N. (2019). A Study on Vocabulary-Learning Problems Encountered by BA English Majors at the University Level of Education. Arab World English Journal, 10(3), 81-98. https://doi.org/10.24093/awej/vol10no3.6

Basal, A., Yilmaz, S., Tanriverdi, A., \& Sari, L. (2020). Effectiveness of Mobile Applications in Vocabulary Teaching. Contemporary Educational Technology, 7(1). https://doi.org/10.30935/cedtech/6162

Budiman, A. (2017). Behaviorism in Foreign Language Teaching. English Franca, 1(02), 101114.

Chang, C. C., Yan, C. F., \& Tseng, J. S. (2012). Perceived convenience in an extended technology acceptance model. Mobile Technology and English Learning for College Students, 28(5), 809-826. http://www.scopus.com/inward/record.url?scp=84865568921\&partnerlD=8YFLogxK\%5 Cnhttp://www.scopus.com/inward/citedby.url?scp=84865568921\&partnerID=8YFLogx 
$\mathrm{K}$

Deris, F. D., \& Shukor, N. S. A. (2019). Vocabulary learning through mobile apps: A phenomenological inquiry of student acceptance and desired apps features. International Journal of Interactive Mobile Technologies, 13(7), 129-140. https://doi.org/10.3991/ijim.v13i07.10845

Gangaiamaran, R., \& Pasupathi, M. (2017). Review on use of mobile apps for language learning. International Journal of Applied Engineering Research, 12(21), 11242-11251.

Hashim, H. (2018). Application of technology in the digital era education. 01(02), 1-5. https://doi.org/10.24036/002za0002

Hashim, H., Md. Yunus, M., Amin Embi, M., \& Mohamed Ozir, N. A. (2017). Mobile-assisted Language Learning (MALL) for ESL Learners: A Review of Affordances and Constraints. Sains Humanika, 9(1-5). https://doi.org/10.11113/sh.v9n1-5.1175

Hashim, H., Yunus, M. M., \& Embi, M. A. (2016). Pre-University English as Second Language (ESL) Learners' Attitude towards Mobile Learning. Creative Education, 07(08), 11471153. https://doi.org/10.4236/ce.2016.78119

Ismail, N., Zaid, S., Mohamed, M., \& Rouyan, N. (2017). Vocabulary Teaching and Learning Principles in Classroom Practices. Arab World English Journal, 8(3), 119-134. https://doi.org/10.24093/awej/vol8no3.9

Kacetl, J., \& Klímová, B. (2019). Use of smartphone applications in english language learningA challenge for foreign language education. Education Sciences, 9(3), 1-9. https://doi.org/10.3390/educsci9030179

Lee, Y., Kozar, K. A., \& Larsen, K. R. T. (2003). The Technology Acceptance Model: Past, Present, and Future. Communications of the Association for Information Systems, 12(January 2003). https://doi.org/10.17705/1cais.01250

Lei, Z. (2018). Vocabulary Learning Assisted with Smart Phone Application. Theory and Practice in Language Studies, 8(11), 1511. https://doi.org/10.17507/tpls.0811.17

Liu, D. (2015). A Critical Review of Krashen's Input Hypothesis : Three Major Arguments. 4(4), 139-146. https://doi.org/10.15640/jehd.v4n4a16

Makoe, M., \& Shandu, T. (2018). Developing a mobile app for learning english vocabulary in an open distance learning context. International Review of Research in Open and Distance Learning, 19(4), 208-221. https://doi.org/10.19173/irrodl.v19i4.3746

Pazilah, F. N. P., Hashim, H., \& Yunus, M. M. (2019). Using Technology in ESL Classroom: Highlights and Challenges. Creative Education, 10(12), 3205-3212. https://doi.org/10.4236/ce.2019.1012244

Pindeh, N., Suki, N. M., \& Suki, N. M. (2016). User Acceptance on Mobile Apps as an Effective Medium to Learn Kadazandusun Language. Procedia Economics and Finance, 37(16), 372-378. https://doi.org/10.1016/s2212-5671(16)30139-3

Rafiq, K. R. M., Hashim, H., Md Yunus, M., \& Norman, H. (2020). iSPEAK: Using mobile-based online learning course to learn "english for the workplace." International Journal of Interactive Mobile Technologies, 14(8), 19-31.

https://doi.org/10.3991/IJIM.V14I08.13185

Rafiq, K. R. M., Hashim, H., Yunus, M. M., \& Pazilah, F. N. (2019). Developing a MOOC for communicative english: A battle of instructional designs. International Journal of Innovation, Creativity and Change, 7(7), 29-39.

Robert A. Bjork, J. F. K. (2018). 乳鼠心肌提取 HHS Public Access. Physiology \& Behavior, 176(1), 139-148. https://doi.org/10.1016/j.physbeh.2017.03.040 
Shen, W. (2003). Current trends of vocabulary teaching and learning strategies for EFL settings. Fen Chia Journal of Humanities and Social Science, 7, 187-224. http://scholar.google.com/scholar?hl=en\&btnG=Search\&q=intitle:Current+Trends+of+ Vocabulary+Teaching+and+Learning+Strategies+for+EFL+Settings $\# 0$

Steel, C. (2012). Fitting learning into life: Language students' perspectives on benefits of using mobile apps. ASCILITE 2012 - Annual Conference of the Australian Society for Computers in Tertiary Education, January 2012, 875-880.

Teng, F. (2014). Research into practice: Strategies for teaching and learning vocabulary. Beyond Words, 2(2), 44-56.

Wang, B.-T. (2017). Designing Mobile Apps for English Vocabulary Learning. International Journal of Information and Education Technology, 7(4), 279-283. https://doi.org/10.18178/ijiet.2017.7.4.881

Xuelian, W. (2018). Influence of Behaviorism to English Vocabulary Teaching. 6(5), 17-20.

Yang, S. C., \& Chen, Y. J. (2007). Technology-enhanced language learning: A case study. Computers in Human Behavior, 23(1), 860-879.

https://doi.org/10.1016/j.chb.2006.02.015 